University of Nebraska - Lincoln

DigitalCommons@University of Nebraska - Lincoln

$10-1-1990$

\title{
Risk-Based Oversight of Experiments in the Environment
}

Henry I. Miller

Food and Drug Administration

Robert H. Burris

University of Wisconsin, Madison, Wisconsin

Anne K. Vidaver

University of Nebraska-Lincoln, avidaver1@unl.edu

Nelson A. Wivel

Office of Recombinant DNA Activities, National Institute of Health, Bethesda, MD

Follow this and additional works at: https://digitalcommons.unl.edu/plantpathpapers

Part of the Plant Pathology Commons

Miller, Henry I.; Burris, Robert H.; Vidaver, Anne K.; and Wivel, Nelson A., "Risk-Based Oversight of Experiments in the Environment" (1990). Papers in Plant Pathology. 84.

https://digitalcommons.unl.edu/plantpathpapers/84

This Article is brought to you for free and open access by the Plant Pathology Department at DigitalCommons@University of Nebraska - Lincoln. It has been accepted for inclusion in Papers in Plant Pathology by an authorized administrator of DigitalCommons@University of Nebraska - Lincoln. 


\title{
Risk-Based Oversight of Experiments in the Environment
}

\author{
Henry I. Miller, Robert H. Burris, Anne K. Vidaver, Nelson A. Wivel
}

$\mathrm{T}$ He new biology has COME of age. Basic Research in fields ranging from immunology to plant biology has been transformed so as to be almost unrecognizable to those whose biology education ended before 1970. The spillover into commercial development likewise has been remarkable. Hardly a week passes without news of some new advance in an area such as therapeutics, vaccines, or plants and animals for food, feed, or fiber.

These uses of biotechnology in "contained" laboratories, pilot plants, greenhouses, and production facilities have engendered little controversy. The National Institutes of Health Guidelines for Research Involving Recombinant DNA have exempted from oversight more than $95 \%$ of laboratory experiments (1); this has allowed organisms of low risk to be handled under modest containment conditions that permit large numbers of living organisms to be present in the workplace and even to be released from the laboratory (2). Despite extensive work in thousands of laboratories throughout the United States with millions of individual genetic clones, there has been no report of their causing a human illness nor any injury to the environment.

A bleak spot in this picture is tests in the environment, often termed field trials, planned introductions, or deliberate releases. A number have been subjected to extreme regulatory scrutiny and lengthy delays solely because recombinant DNA techniques were employed in the manipulation of the organism. This has occurred even when the genetic change was completely characterized, benign, and the organism demonstrably innocuous. The ripple effects have been substantial. Investigators have shied away from areas of research that require field trials of recombinant organisms (3); companies have felt compelled to eschew the newest, most precise and powerful techniques in favor of cruder but less regulated ones (4); and investors have avoided companies whose recombinant DNA-derived products require field trials (5).

Government agencies have variously regulated new biotechnology products with previously existing regimes or crafted new ones. Whether new or old, certain cardinal principles apply. First, triggers to regulation-the criteria for the oversight net-must be scientifically defensible. Second, the degree of oversight must be commensurate with risk. Thus, the regulation scheme generally should be riskbased. Some have contended that this is obvious in theory but difficult to achieve in practice. Critics of risk-based oversight contend that if we knew a priori what experiments were risky, we would have little need for risk assessments and that at the outset we could just exempt those proposals that pose negligible risk. This is a specious assertion. The United States and other nations have often devised regulatory nets based on assumptions about the magnitude

H. I. Miller is in the Office of Brotechnology, Food and Drug Administration, Rockille, MD 20857; R. H. Burris is in the Department of Biochemistry, University of Wisconsm, Madison, WI 53706; A. K. Vidaver is in the Department of Plant Pathology. University of Nebraska. Lincoln. NE 68583; and N. A. Wivel is in the Office of Recombinant DNA Activities, National Institutes of Health, Bethesda, MD 20894 . or the distribution of risk. For example, we require permits for field trials with certain organisms considered to be plant pests, whereas we exempt similar organisms on the basis of a knowledgeable assessment of predicted relative risk; a specific example is the classification of Agrobacterium tumefaciens as a pest under the regulations of the Plant Pest Act, whereas closely related Agrobacterium radiobacter is exempt from regulation. The validity of these assumptions determines the integrity of the regulatory scheme; without them, we might as well flip a coin or exempt field trials proposed on certain days of the week.

The federal government's 1986 "Coordinated framework for the regulation of biotechnology" focused oversight and regulatory triggers on the characteristics of products and on their intended use, rather than on processes used for genetic manipulation. For example, in choosing alternatives to process-based approaches, the Environmental Protection Agency (EPA) "carefully considered how well the options approximated risk," attempting to define experiments that have "high potential for widespread exposure, adverse effects, or uncertainty concerning potential effects to deserve particular regulatory scrutiny" (6).

Since the coordinated framework was published, both the U.S. Department of Agriculture (USDA) and the EPA have labored to create oversight regimes for tests in the environment. They have benefited from National Academy of Sciences (NAS) and National Research Council (NRC) policy documents. Among the most significant conclusions and recommendations from the NAS policy statement are the following: (i) "[ $\mathrm{t}]$ here is no evidence of the existence of unique hazards either in the use of rDNA [recombinant DNA] techniques or in the movement of genes between unrelated organisms" (7, p. 22); (ii) "[ $t$ ]he risks associated with the introduction of rDNA-engineered organisms are the same in kind as those associated with the introduction of unmodified organisms and organisms modified by other methods" (7, p. 22); and (iii) "[a]ssessment of the risks associated with introducing recombinant DNAengineered organisms into the environment should be based on the nature of the organism and the environment into which it is introduced," (7, p. 22) and independent of the method of engineering.

In a more comprehensive report on this subject, an NRC committee concluded that (i) the product of genetic modification and selection constitutes the primary basis for decisions about the environmental introduction of a plant or microorganism, and not the process by which the product was obtained; (ii) although knowledge about the process used to produce a genetically modified organism is important in understanding the characteristics of the product, the nature of the process is not a useful criterion for determining the amount of oversight; and (iii) organisms modified by modern molecular and cellular methods are governed by the same physical and biological laws as are organisms produced by classical methods (8). The NRC proposed to base the evaluation of experi- 
mental field testing on three considerations: familiarity, that is, similarity to introductions with a safe history; ability to confine or control the spread of the organism; and likelihood of harmful effects in case of a mishap.

In spite of this guidance, several recent regulatory proposals have been based on process. The European Economic Community (EEC) recently adopted process-based directives (9) that are applicable to both contained uses and planned introductions of genetically modified organisms and are likely to hinder research and development throughout Europe.

A similar recent domestic proposal for process-based regulation in the United States would require case-by-case risk assessment for all rDNA-manipulated organisms with phenotypes that do not exist in nature because such organisms are "unfamiliar," and by extension, high risk (3). The proposal focuses on a process-determined definition of "familiarity," and inappropriately equates this with safety. The proposal exempts from oversight experiments with organisms that are "familiar," defined solely by the test organisms being "natural" or having been created by older, more "familiar" genetic manipulation techniques. If an organism meets this definition, it is exempt from this regulatory net, however pathogenic, invasive, or otherwise worrisome it may be.

Can one devise a scientifically defensible, risk-based scheme for oversight that is also workable? We think so, and propose an algorithm for which we have borrowed from previous ideas and proposals of government agencies, primarily NIH and the USDA. It is based on the nature of the organism and of the site into which the organism is to be introduced, and is adaptable to the demands of many oversight and regulatory agencies. The algorithm accommodates any organism, whether "natural," one that has been selected by any technique, or one that has been manipulated by long-established or new techniques of genetic engineering.

In order to ascertain the degree of oversight of a wild-type, unmodified, or parental organism required in a field trial, we first determine the overall level of concern on the basis of scientific knowledge and experience as compiled and tabulated by experts. That level of safety concern is entered into another table in which the "confinement level," that is, the site and conditions for the experiment, is considered; this enables us to read off the level of required oversight. The levels can include exempt, notification of a local biosafety committee, prior approval by a local biosafety committee, notification of a federal agency, or prior approval by a federal agency. In such a scheme, the relation among levels of safety concern, confinement, and oversight can be varied to take into account concerns such as the desired amount of scrutiny, public perceptions, and the regulatory burden on researchers and the government.

In order to determine the degree of oversight of an organism altered from wild type by any process, we proceed as before but add one step. After ascertaining the initial "overall level of concern," we determine whether the modification has altered the safety level. If so, that new level of safety concern is used to establish the degree of oversight (10).

Many refinements of this scheme are possible. For example, a table that lists organisms according to safety categories could differentiate species within a genus or even strains within a species as having important differences in characteristics and different levels of safety concern.

The scientific community has concurred that appropriate oversight and regulation of biotechnology are justified and has exercised laudable care in the application of new genetic techniques. As a result, to our knowledge not a single untoward event has occurred while applying them to the pursuit of basic and commercial research. With the benefit of theory and practice, oversight and regulatory agencies have reevaluated and relaxed their regimes somewhat. Continued oversight and regulation should be based on the properties of organisms-phenotypes-and not on the techniques employed to alter their genetic constitution. Although consideration of processes may be useful to risk assessment, product, not process, must govern the triggers to oversight and regulation. We propose here a paradigm for the oversight of field trials that is scientifically defensible (11), can be refined, and is broadly applicable.

\section{REFERENCES AND NOTES}

1. "Guidelines for research involving recombinant DNA," Fid Regpts 51, 16958 (1986).

2. D. R. Lincoln, E. S Fisher, D. Lambert, M. A. Chatigny, M. A Levin, "Release and containment of microorganisms from applied genetics activities," report submitted to EPA in fulfillment of grant R-808317-01 (1983)

3. M. Ratner, "BSCC addresses scope of oversight," Bio/teclnology 8, 196 (1990). Sec also, "UW researchers stymied by genctic test limits," Captial 7 tmes, Madison, WI, 16 March 1988, p. 31.

4. "Clouds gather over the botech industry, Wall Street Journal, 30 January 1989, p. 11 .

5. H. I. Miller, "Governmental regulation of the products of the new biotechnology: A U.S. perspective," in Advances in Biotechnology, Proceedings of an International Conference Organized by the Swedish Councl for Forestry and Agricultural Research and the Suedish Recombinant DNA Committee (Boktryck HBG, Stockholm, Sweden, 1990)

6. "Coordinated framework for regulation of biotechnology," Fed Regrst 51, 23315 (1986).

7. National Academy of Sciences, "Introduction of recombınant DNA-engincered organisms into the environment: Kev issues" (Natıonal Academv Press, Washing ton, DC, 1987)

8. National Research Council, "Field testıng genetıcally modificd organısms Framework for decisıons" (National Academy Press, Washington, DC, 1989). Anımals were not discussed in the National Research Council report, but the same general principles should apply to them as to plants and microorganısms.

9. See "New European release rules ratıfied," Nature 344, 371 (1990).

10. A complete version of this proposal, including tables, mav be obtancd from H. I. Miller, FDA, Mall Code HF-6, 5600 Fishers Lane, Rockville, MI) 20857

11. E. L. Korwek, Chem. Regul. Rep., 16 February 1990, p. 1454 